\title{
The writing of informed consent in accessible language: difficulties
}

\section{A redação do termo de consentimento livre e esclarecido em linguagem acessível: dificuldades}

Nurimar C. Fernandes

\author{
A B S T R A C T
}

\begin{abstract}
In order to assess the adequacy of informed consent terminology of research projects developed at the Clementino Fraga Filho University Hospital (Federal University of Rio de Janeiro), we conducted a review study on the terminology found in 55 projects (200820013). Such projects belonged to different medical specialties and were all registered in the hospital's Ethics in Research Committee. Patients had difficulty in understanding the meanings of 76 medical terms and expressions; only 12 of them could be replaced. On the other hand, the present study reached the conclusion that, in most cases, the writing with scientific terms is essential in items such as justification/objectives and procedures, being insurmountable obstacles to the participants of this research and patients' understanding.
\end{abstract}

Key words: Informed consent. Biomedical research. Bioethics. Writing. Terminology. Comprehension.

\section{INTRODUCTION}

$T^{\text {re }}$ he Declaration of Helsinki was broader than the Nuremberg Code, establishing the free and informed consent as a standard for accepted procedures in a ethical research. It is a very complex procurement document, since a lot of information must be provided to research participants in a simple and understandable way. To be truly free and informed, what is being consented should be clearly understood.

This study aims to assess the adequacy of terms from informed consent forms (ICF) of research projects developed at a university hospital.

\section{METHODS}

This was a review study (2008-2013) of the ICFs from Project of the are of Health Sciences - Medicine, registered in the Comitê de Ética em Pesquisa of the Hospital Universitário Clementino Fraga Filho, Universidade Federal do Rio de Janeiro (CEP-HUCFF/UFRJ).

The committee, whose members include one representative from the users, analyzed fifty-five projects of the specialties Anesthesiology, Cardiology, Surgery, Dermatology, Infectious and Parasitic Diseases, Endocrinology, Gastroenterology, Geriatrics, Gynecology,
Hematology, Hepatology, Immunology, Nephrology, Neurology, Oncology, Ophthalmology, Orthopedics, Otorhinolaryngology, Pulmonology, Psychiatry, Radiology and Rheumatology.

\section{RESULTS}

The following words/phrases $(n=76)$ were considered difficult to understand and replacement by nontechnical terms: 1) thiobarbituric acid, 2) endotracheal diffuse involvement , 3) retinal cells electrophysical findings, 4) low grade prostate adenocarcinoma, 5) antiendomysium antibody IgA, 6) non-steroidal anti-inflammatory agents, 7) non-probabilistic sample, 8) opioid analgesics, 9) anti-gliadin antibody, 10) social movement actors, 11) salivary scintigraphy, 12) understand perceptions about the disease. 13) demographic characteristics, 14) coagulopathy, 15) cohort, 16 liver cirrhosis, 17) coinfection, 18) choroidopathy, 19) corneal scarring, 20) dense cataract, 21) double-blind design, 22) breast density, 23) extraction / amplification / sequencing / quantification of DNA, 24) hepatic encephalopathy, 25) prospective / retrospective / Crosssectional study, 26) risk stratification, 27) insulin-like growth factor, 28) neurocognitive function, 29) serum pharmacokinetics, 30) pituitary transcription factors, 31) genotype, 32) genome, 33) encoding genes, 34) portal

1. Serviço de Dermatologia, Hospital Universitário Clementino Fraga Filho, Universidade Federal do Rio de Janeiro. Comitê de Ética em Pesquisa, Hospital Universitário Clementino Fraga Filho, Universidade Federal do Rio de Janeiro - RJ - Brazil. 
hypertension 35) contained distal herniation, 36) vitreous hemorrhage, 37) occult infection, 38) measurement of portal vein pressure gradient, 39) myelosuppression, 40) serum levels of hemoglobin and bilirubin, 41) serum levels of nitric oxide, 42) neurolysis, 43) peripheral neuropathy, 44) clinical research, performance status 45), 46) risk potential, 47) exploratory research, 48) pneumothorax, 49) prospects for the future, 50) peptides, 51) spontaneous bacterial peritonitis, 52) protein carbonylated, 53) analogue pictorial questionnaire, 54) psychosis, 55) cutaneous rash; 56) diabetic retinopathy, 57) randomized, 58) nonrandom selection, 59) genetic sequencing, 60) sialometry, 61) psychological symptoms, 62), serology 63) histological subtype of Hodgkin's lymphoma, 64) viral susceptibility, 65) prevalence rate, 66) molecular biology technique, 67) biological therapy, 68) cognitive behavioral therapy, 69) optical coherence tomography, 70) toxicity, 71) pressure transmitter, 72) generalized anxiety disorder, 73) antiretroviral treatment, 74) nucleotide treatment, 75) non-infectious uveitis, 76) invasive mechanical ventilation.

For the following words $(n=12)$ replacements were possible: 1) aneurysm - dilation (increase) in a blood vessel, 2) disease course - what happens during an illness, 3) glucose curve - are the measures of blood sugar at a certain time, 4) adverse effects - are the negative effects that a medicine can cause, 5) exacerbation of the disease - the disease worsens, 6) noninvasive test - is the test that does not cut or pierces to skin, 7) nasal endoscopic exam - the exam is done inside the nose, 8) benign prostatic hyperplasia - is an increase in prostate size that is not malignant, 9) Post-inflammatory hyperpigmentation - is the darkening of the skin that can happen after a inflammation, 10) serum bilirubin levels - is the amount of a pigment produced in the liver that is found in the blood, 11) skin rash - red spots on the skin that can itch; they are caused by drugs or disease-causing microbes, 12) toxicity-bad for health".

\section{DISCUSSION}

The epistemological question is obstacle to obtaining an informed consent; although the common sense and low-tech mechanism to spend more time talking to the participants of the study appears promising, the wording without scientific terms is, in most cases, an insurmountable obstacle in the sections of justification, objectives and procedures.

Confidence in the doctor affected the decision to participate in the clinical trial of the drug², there being also the influence of the patients' level of education. Other authors point out that even the text improvements through a syntactic lexical approach or workgroup did not impact final understanding ${ }^{3}$. The word choice is a particular challenge, as it requires a level of understanding that goes beyond the usually required in health assistance ${ }^{1,4}$. Biondo-Simões et al. argue that research participants should be those bettereducated, with customary character for reading, with easy access to the internet and at a higher income group ${ }^{5}$.

A recent review showed that understanding of the information about the study varies among participants, both in developing countries and in developed ones ${ }^{6}$. This fact highlights the complexity of the issue, since it was also shown that when it comes to randomized and controlled designs, understanding is compromised in both. Participants in developing countries are less likely to refuse to participate in research or to leave it, more concerned about the consequences of their decisions.

The readability of consent forms is a major problem for the ethics in research committees, researchers and research participants. The exclusion of technical terms is often the only way to reach it.

\section{R E S U M O}

Com o objetivo de avaliar a adequação dos textos do termo de consentimento livre e esclarecido de projetos de pesquisa desenvolvidos no Hospital Universitário Clementino Fraga Filho (Universidade Federal do Rio de Janeiro), foi realizado (2008-2013) um estudo de revisão da terminologia encontrada em 55 projetos. Tais projetos, todos registrados no Comitê de Ética em Pesquisa do hospital, pertenciam a diferentes especialidades médicas. Os participantes tiveram dificuldades em compreender os significados de 76 termos médicos e expressões; apenas 12 deles puderam ser substituídos. Por outro lado, o presente estudo chegou à conclusão de que, na maioria dos casos, a redação com termos científicos é essencial em itens como justificativa/objetivos e procedimentos, constituindo obstáculos intransponíveis para a compreensão dos participantes desta pesquisa e dos pacientes.

Descritores: Consentimento livre e esclarecido. Pesquisa biomédica. Bioética. Redação. Terminologia. Compreensão.

\section{REFERENCES}

1. Rossi R, Goldim JR, Francisconi CF. Glossário de termos científicos para elaboração do consentimento informado. Rev Med ATM. 1999;19(1):304-9.
2. Meneguin S, Zoboli ELCP, Domingues RZL, Nobre MR, César LAM. Entendimento do termo de consentimento por pacientes partícipes em pesquisas com fármaco na cardiologia. Arq Bras Cardiol. 2010;94(1):4-9. 
3. Paris A, Brandt C, Cornu C, Maison P, Thalamas C, Cracowski JL. Informed consent document improvement does not increase patients' comprehension in biomedical research. $\mathrm{Br} J$ Clin Pharmacol 2010;69(3):231-7

4. Goldim JR. Consentimento e informação: a importância da qualidade do texto utilizado. Rev HCPA Fac Med Univ Fed Rio Gd do Sul. 2006;26(3):117-22.

5. Biondo-Simões MLP, Martynetz J, Ueda FMK, Olandoski M. Compreensão do termo de consentimento informado. Rev Col Bras Cir. 2007;34(3):183-8.

6. Mandava A, Pace C, Campbell B, Emanuel E, Grady C. The quality of informed consent: mapping the landscape. A review of empirical data from developing and developed countries. J Med Ethics. 2012;38(6):356-65.
Received on 18/02/2015

Accepted for publication 20/03/2015

Conflict of interest: none.

Source of funding: none.

\section{Adress for correspondence:}

Nurimar C. Fernandes

E-mail: nurimarfernandes@terra.com.br 